\title{
Mycoplasmas and recurrent oral ulceration
}

\author{
A. M. GORDON, H. M. DICK, D. K. MASON, W. MANDERSON, AND W. B. CRICH TON
}

From the Department of Bacteriology, Royal Infirmary, Glasgow, and Dental School, Glasgow

SYNOPSIS A controlled cultural and serological investigation of mycoplasmas in recurrent oral ulceration was undertaken. No evidence for an aetiological relationship between oral mycoplasmas and this condition was obtained.

Mycoplasmas, principally $M$. orale, were frequently recovered from the oral cavities of individuals with natural teeth, but rarely from edentulous subjects.

Although the occurrence of recurrent oral ulceration (Mikulicz and Kümmel, 1898) has been recorded in medical and dental literature since the time of Hippocrates (460-370 B.C.), the aetiology of this condition is unknown. Many different aetiological factors have been suggested-vitamin deficiency, bacterial and viral infections, and hormonal imbalance-but all remain unproven (Sircus, Church, and Kelleher, 1957; Ship, Merritt, and Stanley, 1962; Scott, 1965).

More recently, however, two new concepts have emerged. First, that recurrent oral ulceration has the clinical, histopathological, and serological features of an autoimmune disease (Lehner, 1964, 1965 and 1967). Secondly, that the condition is caused by an infection with bacterial ' $L$ ' form organisms (Barile, Graykowski, Driscoll, and Riggs, 1963; Graykowski, Barile, and Stanley, 1964). However, considerable confusion has arisen in attempts to differentiate bacterial ' $L$ ' forms from true mycoplasmas and it has not always been apparent from previous reports which group of microorganisms was being discussed. This controlled study has been undertaken to investigate the prevalence of true oral mycoplasmas in 33 patients with recurrent ulceration of the mouth.

\section{METHODS}

CLINICAL MATERIAL Thirty-three individuals (nine males and 24 females; age range 11 to $63 \mathrm{yr}$.: mean age $30 \cdot 3 \mathrm{yr}$.) with recurrent oral ulceration were investigated. These patients were subdivided on clinical grounds into the following categories: Mikulicz type of recurrent oral ulceration, 28 cases: herpetiform type of recurrent oral ulceration, 3 cases: Behcet's syndrome, 2 cases. Thirtyone of the patients had oral ulcers only, one had both oral and vaginal ulcers, and one had oral, vaginal, and conjunctival lesions. The ulcers were classified according to their clinical severity, as mild in 11 cases, as moderately severe in 13, and as severe in nine subjects. None of the

Received for publication 8 May 1967. pa tients had clinical evidence of systemic illness. Twentyfour had natural teeth only, and nine were edentulous.

Two groups of patients were utilized for the collection of control specimens in this study. The first group comprised 39 healthy individuals ( 12 males and 27 females: age range 17 to $73 \mathrm{yr}$.: mean age $43.7 \mathrm{yr}$.) with no personal experience or family history of recurrent oral ulceration. Fifteen of these subjects had natural teeth, and 24 were edentulous. A second group of 48 subjects (11 males and 37 females: age range 14 to 77 yr.: mean age $36 \cdot 2$ yr.) was utilized as an additional control group for the serological part of this study. None of these individuals had a history of recurrent ulceration of the mouth. Twenty-eight had natural teeth and 20 were edentulous.

SPECIMEN COLLECTION Specimens of saliva and buccal mucosal swabs from the ulcer area were collected from each of the 33 ulcer patients, and from the first group of 39 controls. In addition, biopsies were taken from the buccal mucosae of nine individuals who had particularly florid ulcers. Samples of venous blood $(10 \mathrm{ml}$.) were collected from the recurrent ulcer group, and from both control groups. The saliva, swabs, and biopsies were transmitted to the laboratory in sterile bottles containing 2 to $3 \mathrm{ml}$. of a buffered $10 \%$ bovine albumin broth (bovine albumin, fraction V, Armour) supplemented with penicillin $(10,000$ units per ml.) and thallium acetate (in a final concentration of $1: 2,000$ ).

CULTIVATION OF MYCOPLASMAS For the isolation of mycoplasmas from these specimens, media comprising P.P.L.O. agar and P.P.L.O. broth (Difco, without crystal violet) $70 \mathrm{ml}$., horse serum (Burroughs Wellcome, No. 3, unheated) $10 \mathrm{ml}$, yeast extract (fresh $25 \%$ extract of baker's yeast) $10 \mathrm{ml}$, and boiled blood extract $10 \mathrm{ml}$., were used. Penicillin (10,000 units per ml.) and thallium acetate (final concentration of $1: 2,000$ ) were included as bacterial inhibitors. The components of these media were stored at $+4^{\circ} \mathrm{C}$. in small quantities, and fresh agar plates and bottles of broth were prepared when required.

Before inoculation, the biopsies were homogenized, with the aid of sterile P.P.L.O. broth, in a Tenbroeck tissue grinder. Then $0.2 \mathrm{ml}$. of the fluid homogenized 
material, $0.2 \mathrm{ml}$. of untreated saliva, and $0.5 \mathrm{ml}$. of the transport broth, into which the cellular material on the buccal swabs had been expressed, constituted the final inocula. P.P.L.O. agar plates were inoculated, in duplicate, from each specimen, one plate being incubated under increased $\mathrm{Co}_{2}$ tension, and the other under strictly anaerobic conditions. All plates were incubated at $37^{\circ} \mathrm{C}$. for five days. Similar inocula, from each specimen, were made into $10 \mathrm{ml}$. of P.P.L.O. broth. Following incubation at $37^{\circ} \mathrm{C}$. for 72 hours the broths were subcultured to P.P.L.O. agar, and the plates were incubated under conditions similar to those of the primary plates, for five days.

IDENTIFICATION OF MYCOPLASMAS Mycoplasma colonies were provisionally identified by their characteristic 'friedegg' colonial appearance when viewed by oblique illumination under a low power objective. In order to avoid confusion with possible bacterial ' $L$ ' forms, final identification of these organisms as mycoplasmas was dependent upon their successful and stable subculture on P.P.L.O. agar devoid of penicillin. Species identification of the oral mycoplasma isolates was carried out by the technique of growth inhibition described by Clyde (1964), using specific hyperimmune rabbit sera.

PREPARATION OF MYCOPLASMA ANTIGENS AND OF HYPERIMMUNE SERA The strains of Mycoplasma orale and Mycoplasma hominis type I were received from Dr. B. E. Andrews, Director of the Mycoplasma Reference Laboratory, Colindale, London. Following initial passage in P.P.L.O. horse serum broth, the mycoplasmas were adapted to growth in P.P.L.O. rabbit serum broth. Ten per cent inocula of each adapted mycoplasma were made into $500 \mathrm{ml}$. aliquots of rabbit serum broth, and the cultures were incubated aerobically at $37^{\circ} \mathrm{C}$. for 72 hours. The organisms were harvested by sedimentation of the broths in a model L-2 Spinco ultracentifuge at 19,000 r.p.m., and the resulting pellets were resuspended in $1 / 50$ th the original volume in distilled water. The resuspended pellets were subsequently ultrasonicated in an M.S.E. $100 \mathrm{w}$ ultrasonic disintegrator, employing $10 \mathrm{~K} / \mathrm{c}$ for 20 minutes, and the resulting antigens were stored in ampoules at $-20^{\circ} \mathrm{C}$. until required for indirect haemagglutination tests.

Hyperimmune sera against each mycoplasma were prepared in young Dutch strain rabbits, using complete Freund adjuvant.

INDIRECT HAEMAGGLUTINATION (I.H.A.) TECHNIQUE The method used was that described by Taylor-Robinson, Canchola, Fox, and Chanock (1964) with minor modifica- tions. Four per cent washed sheep cells in phosphate buffer $\left(p \mathrm{H} \mathrm{7.2)}\right.$ were incubated at $37^{\circ} \mathrm{C}$. for 30 minutes with an equal volume of $1: 20,000$ tannic acid in saline. After washing in buffered saline $(p \mathrm{H} \mathrm{7 \cdot 2})$, the $2 \%$ tanned cells were incubated with an aliquot of antigen at a dilution previously determined by chessboard titration against the rabbit hyperimmune serum. The tanned cells were sensitized by incubating at $37^{\circ} \mathrm{C}$. for 30 minutes, and then spun and washed twice in buffer $(p H 7 \cdot 2)$ containing heat-inactivated rabbit serum at a dilution of $1 / 100$. The tanned sensitized cells were finally resuspended to $1 \%$ in this buffered saline, with 1/100 normal rabbit serum.

The human sera to be titrated were inactivated at $56^{\circ} \mathrm{C}$. for 30 minutes, and diluted 1 in 5 with buffer before absorption for 30 minutes at room temperature with washed packed sheep cells. The absorbed, inactivated sera were then diluted in buffer containing 1/100 normal rabbit serum.

The test proper was carried out in Perspex plates, using $0.1 \mathrm{ml}$. of serum dilution, and $0.1 \mathrm{ml}$. of tanned sensitized cells. Controls consisted of each serum at $1 / 5$ dilution with tanned unsensitized cells, and appropriate cell controls (for tanned, tanned sensitized, and untanned cells). Each rabbit hyperimmune serum was titrated with each experiment. The plates were left at room temperature for two hours, and $50 \%$ agglutination of the sensitized red cells was considered the endpoint. Control titrations were also carried out using uninoculated growth medium to prepare 'antigen' in exactly the same way as the mycoplasma antigens: these controls were negative throughout. Absorption and inhibition of haemagglutination was demonstrated by absorbing the positive sera with an aliquot of antigen for one hour at room temperature and repeating the indirect haemagglutination tests, which were consistently negative.

\section{RESULTS}

Table I shows the frequency of recovery of mycoplasmas from the mouths of the aphthous ulceration and control groups. Mycoplasmas were isolated from the saliva of 15 of the 33 patients with recurrent ulcers, and from the saliva of eight out of 39 healthy controls. In both groups, $M$. orale was the species most commonly recovered.

The results of indirect haemagglutination tests (I.H.A.) with $M$. orale and $M$. hominis I antigens on the sera of patients with recurrent aphthous ulceration are summarized in Table II. Indirect haemagglutination titres of $1 / 25$ or greater against M.orale were

TABLE I

CULTURAL RESULTS

\begin{tabular}{|c|c|c|c|c|c|c|c|c|}
\hline \multirow[t]{2}{*}{ Group } & \multirow[t]{2}{*}{ No. } & \multicolumn{6}{|c|}{ Mycoplasmas } & \multirow{2}{*}{ Total } \\
\hline & & M. orale & M. salivarium & M. hominis I & M. fermentans & M. pneumoniae & Untyped & \\
\hline $\begin{array}{l}\text { Recurrent aphthous } \\
\text { ulceration } \\
\text { Control }\end{array}$ & $\begin{array}{l}33 \\
39\end{array}$ & $\begin{array}{r}10 \\
4\end{array}$ & $\begin{array}{l}2 \\
1\end{array}$ & $\begin{array}{l}1 \\
1\end{array}$ & $\begin{array}{l}\mathbf{0} \\
\mathbf{0}\end{array}$ & $\begin{array}{l}\mathbf{0} \\
\mathbf{0}\end{array}$ & $\begin{array}{l}2 \\
2\end{array}$ & $\begin{array}{c}15(45.5 \%) \\
8(20.5 \%)\end{array}$ \\
\hline
\end{tabular}


TABLE II

SEROLOGICAL RESULTS

\begin{tabular}{lll} 
Group No. & $\begin{array}{l}\text { Indirect Haemagglutination } \\
(\text { Titres } \geqslant 1 / 25)\end{array}$ \\
\hline M. orale & M. hominis I
\end{tabular}

Recurrent aphthous

ulceration

Control

$\begin{array}{ll}33 & 5 \\ 87 & 3\end{array}$

0

encountered in the sera of five of the 33 recurrent aphthous ulceration patients, and in three of 87 control subjects. No antibodies against $M$. hominis type I were detected in the aphthous ulcer sera.

Table III shows the incidence of mycoplasmas and the occurrence of mycoplasma antibodies in relation to the clinical severity of oral ulcers. No correlation between the presence of oral mycoplasmas and the severity of ulcers was observed. No mycoplasmas were recovered from buccal mucosal biopsies performed on nine severe ulcers.

\section{TABLE III}

MYCOPLASMA ISOLATION AND OCCURRENCE OF ANTIBODIES IN RELATION TO ULCER SEVERITY

\begin{tabular}{lrcc} 
Severity of Ulcers & $\begin{array}{l}\text { Mycoplasma } \\
\text { Isolations }\end{array}$ & $\begin{array}{l}\text { M. orale } \\
\text { Antibodies }\end{array}$ \\
\hline Mild & 11 & 6 & 2 \\
Moderate & 13 & 7 & 2 \\
Severe & 9 & 2 & 1
\end{tabular}

The relation of oral mycoplasmas to the state of dentition of the patients is shown in Table IV. In both pathological and control groups, mycoplasmas were much more frequently recovered from the mouths of individuals with natural teeth than from edentulous subjects.

\section{TABLE IV}

ISOLATION OF ORAL MYCOPLASMAS IN RELATION TO DENTITION

\begin{tabular}{lclrc} 
Group & Dentition & & $\begin{array}{c}\text { Mycoplasma } \\
\text { Isolates }\end{array}$ \\
\hline $\begin{array}{l}\text { Recurrent aphthous } \\
\text { ulceration }\end{array}$ & 33 & $\begin{array}{l}\text { Natural } \\
\text { Artificial }\end{array}$ & 24 & 15 \\
Control & & 9 & 0 \\
& 39 & Natural & 15 & 7 \\
Artificial & 24 & 1
\end{tabular}

\section{DISCUSSION}

Mycoplasmas are known to occur with some frequency in the normal human oropharynx (Morton, Smith, Williams, and Eickenberg, 1951; Smith and Morton, 1951; Burnett and Gilmore, 1959; Shklair, Mazzarella, Gutekunst, and Kiggins, 1962; Razin, Michmann, and Shimshoni, 1964; Clyde, 1964;
Taylor-Robinson et al., 1964). Of the well characterized human prototypes, $M$. hominis type I, $M$. salivarium, $M$. orale, $M$. fermentans, and $M$. pneumoniae, identified in this situation, $M$. salivarium and $M$. orale are the commonest oral inhabitants (Oates, Whittington, and Wilkinson, 1959; Clyde, 1964; Mufson et al., unpublished results; Taylor-Robinson et al., 1964), M. hominis type I and M. pneumoniae having been found much less often (Taylor-Robinson et al., 1964; Clyde, 1964). The role of M. pneumoniae in the aetiology of upper and lower respiratory tract infection has now been well documented (Goodburn, Marmion, and Kendall, 1963; Chanock, James, Fox, Turner, Mufson, and Hayflick, 1962; Grayston, Alexander, Kenny, Clarke Fremont, and MacColl, 1965; Forsyth, Bloom, Johnson, and Chanock, 1965; Hayflick and Chanock, 1965; Andrews, 1965; Feizi, Maclean, Sommerville, and Selwyn, 1967), and an aetiological role has been suggested for $M$. hominis type $\mathrm{I}$ in the development of some cases of exudative pharyngitis and tonsillitis (Mufson, Ludwig, Purcell, Cate, Taylor-Robinson, and Chanock, 1965). On the other hand, neither these nor other mycoplasma species have yet been clearly implicated in the pathogenesis of purely oral disease, although Barile and Sheingorn (1960) recorded the isolation of a pure culture of P.P.L.O. from the dental pulp in a case of acute serous pulpitis.

Various infective theories of recurrent aphthous ulceration have been propounded within recent years. Barile and colleagues (1963) and Graykowski and colleagues $(1964,1966)$ have produced evidence to suggest that transitional ' $L$ ' form organisms derived from $\alpha$-streptococci may be responsible for recurrent aphthous and periadenitis types of ulcers, but true mycoplasmas, as distinct from bacterial ' $L$ ' forms, have received little attention. Apart from the frequency with which mycoplasmas can be demonstrated in the oropharynx, there are theoretical reasons for considering these microorganisms as possible direct or indirect aetiological agents in recurrent aphthous ulceration. The association of Mycoplasma pneumoniae infection with a cold agglutinin serological response (Hayflick and Chanock, 1965) and other immunological changes (Feizi, 1967) suggests that organisms of this kind might cause other conditions characterized by autoimmune serological reactions. Mycoplasmas have previously been associated with some cases of rheumatoid arthritis and Reiter's syndrome (Ford, 1963; Bartholomew and Himes, 1964; Decker and Ward, 1966). There is now clear evidence that an autoimmune mechanism may be involved in recurrent aphthous ulceration (Lehner, 1964, 1965), and in Behcet's syndrome (Lehner, 1967), and it is conceivable that mycoplasma infec- 
tion could initiate such autoimmune reactions by virtue of an antigenic cross-reactivity between these organisms and oral epithelium, such a hypothesis having been suggested by Kramer (1965) and by Lehner (1967). There is in fact good evidence for such a relation between $\beta$-haemolytic streptococci and heart tissue in rheumatic fever (Kaplan, 1963), and between Escherichia coli 014 and colonic mucosa in ulcerative colitis (Perlmann, Hammarström, Lagercrantz, and Gustafsson, 1965).

The present investigation has produced no evidence that oral mycoplasmas are aetiologically implicated in the condition of recurrent oral ulceration. Thus, no correlation was observed between the frequency of isolation of oral mycoplasmas, the presence of significant I.H.A. titres, and the clinical severity of oral ulcers. Furthermore, no mycoplasmas were recovered from homogenized biopsied tissue derived from nine of the subjects at the time of maximum clinical intensity of their periodically severe ulcers. These negative findings are consistent with the recently reported electron microscopic work of Lehner and Sagebiel (1966) who examined oral mucosal biopsies from three subjects suffering from the Mikulicz variety of recurrent aphthous ulceration, three subjects with the herpetiform type of recurrent focal ulceration, and from three healthy controls. No morphological evidence was obtained of virus inclusions, ' $L$ ' forms of bacteria, or mycoplasmas, within the epithelial cells of ulcer biopsies from the Mikulicz aphthae or controls. On the other hand, a viral aetiology of the herpetiform type of recurrent focal ulceration was suggested by the demonstration of intranuclear inclusion bodies in the epithelial cells of herpetiform ulcer biopsies.

It is of interest that oral mycoplasmas were recovered from $45.5 \%$ of the oral ulcer patients and from $20.5 \%$ of the healthy controls, but it is probable that this difference is explicable in terms of the state of dentition of the subjects. It is known that mycoplasmas can be recovered frequently from the mouths of subjects with natural teeth, and rarely from edentulous individuals. Razin et al. (1964), in a study of 138 healthy subjects, isolated mycoplasmas from the gingival sulci of nearly all individuals having natural dentitions, and recovered no mycoplasmas from edentulous mouths.

In the present investigation, $72.7 \%$ of the oral ulcer subjects and $38 \%$ of the controls had natural teeth: only one mycoplasma, a strain of $M$. orale, was recovered from an edentulous mouth.

Antibody to mycoplasma species has been sought by a variety of techniques, including immunofluorescence (Liu, 1957), growth inhibition (Clyde, 1964), and complement fixation (Chanock et al., 1962). All of these techniques have some defect which reduces their value in diagnosing human mycoplasma infection. The indirect haemagglutination method, however, combines the merits of relative simplicity, specificity, and high sensitivity (Friedman and Bennet, 1957; Dowdle and Robinson, 1964; TaylorRobinson, Ludwig, Purcell, Mufson, and Chanock, 1965), and it has been employed to demonstrate human antibody to $M$. hominis type I following experimental infection (Mufson et al., 1965; TaylorRobinson, Fox, and Chanock, 1965). The failure to detect appreciable mycoplasma antibodies by this highly sensitive technique in the sera of patients with recurrent aphthous ulceration would suggest that mycoplasmas are not aetiologically implicated in this condition, although it is important to bear in mind that recent work concerned with surface viral infections (Lancet, 1967) suggests that the main antibody response may be more localized than has hitherto been suspected. The same situation could pertain in surface mycoplasma infections, and it might therefore be relevant in this context to examine the saliva of patients with recurrent aphthous ulceration for mycoplasma antibodies before completely excluding mycoplasmas as aetiological agents in this common form of oral ulceration.

We wish to thank Dr. J. C. J. Ives, of the University Department of Bacteriology, Glasgow Royal Infirmary, for helpful criticism of this paper. Dr. B. E. Andrews, Director, The Mycoplasma Reference Laboratory, Colindale Ave., London, N.W.9, kindly supplied the strains of Mycoplasma orale and Mycoplasma hominis type I.

\section{REFERENCES}

Andrews, B. E. (1965). Proc. roy. Soc. Med., 58, 80

Barile, M. F., and Sheingorn, A. (1960). Oral Surg., 13, 756. 1395, Driscoll, E. J., and Riggs, D. B. (1963). Oral Surg., 16,

Bartholomew, L. E., and Himes, J. (1964). Arthr. and Rheum., 7, 291. Burnett, G. W., and Gilmore, E. (1959). J. dent. Res., n38, 632.

Chanock, R. M., James, W. D., Fox, H. H., Turner, H. C., Mufson, M. A., and Hayflick, L. (1962). Proc. Soc. exp. Biol. (N.Y.), $110,884$.

Clyde, W. A., Jr. (1964). J. Immunol., 92, 958.

Decker, J. L., and Ward, J. R. (1966). Bull. rheum. Dis., 16, 412.

Dowdle, W. R., and Robinson, R. Q. (1964). Proc. Soc. exp. Biol. (N.Y.), 116, 947.

Feizi, T.,(1967). Proc. nat. Acad. Sci. (Wash.), In the press.

Maclean, H., Sommerville, R. G., and Selwyn, J. G. (1967). Brit. med. J., 1, 457.

Ford, D. K. (1963). Arthr. and Rheum., 6, 159.

Forsyth, B. R., Bloom, H. H., Johnson, K. M., and Chanock, R. M. (1965). J. Amer. med. Ass., 191, 364.

Friedman, M., and Bennet, C. R. (1957). Proc. Soc. exp. Biol. (N.Y.), 94, 712 .

Goodburn, G. M., Marmion, B. P., and Kendall, E. J. C. (1963). Brit. med. J., 1, 1266.

Graykowski, E. A., Barile, M. F., and Stanley, H. R. (1964). J. Amer. dent. Ass., 69, 118.

, Lee, W. B., and Stanley, H. R. (1966). J. Amer. med. Ass., 196, 637.

Grayston, J. T., Alexander, E. R., Kenny, G. E., Clarke, E. R., Fremont, J. C., and MacColl, W. A. (1965). Ibid., 191, 369. 
Hayflick, L., and Chanock, R. M. (1965). Bact. Rev., 29. 185.

Hippocrates (5th Century B.C.) Epidemion, Book 3. See Hippocrates (1923). Epidemics, Book III. In Hippocrates, with an English translation by W. H. S. Jones, vol. 1, p. 219 (Loeb Classical Library). Heinemann, London.

Kaplan, M. H. (1963). J. Immunol., 90, 595.

Kramer, I. R. H. (1965). Proc. roy. Soc. Med., 58, 458.

Lehner, T. (1964). Lancet, 2, 1154.

(1965). Guy's Hosp. Gaz., 79, 179.

(1967). Brit. med. J., 1, 465.

, and Sagebiel, R. W. (1966). Brit. dent. J., 121, 454.

Liu, C. (1957). J. exp. Med., 106, 455.

Mikulicz, J. von, and Kümmel, W. (1898). Die Krankheiten des Mundes. Gustav Fisher, Jena.

Morton, H. E., Smith, P. F., Williams, N. B., and Eickenberg, C. F. (1951). J. dent. Res., 30, 415.

Mufson, M. A., Ludwig, W. M., Purcell, R. H., Cate, T. R., TaylorRobinson, D., and Chanock, R. M. (1965). J. Amer. med. Ass. 192, 1146 .
Oates, J. K., Whittington, M. J., and Wilkinson, A. E. (1959). Brit. J. vener. Dis., 35, 184.

Perlmann, P., Hammarström, S., Lagercrantz, R., and Gustafsson, B. E. (1965). Ann. N.Y. Acad. Sci., 124, 377.

Razin, S., Michmann, J., and Shimshoni, Z. (1964). J. dent. Res., 43, 402.

Scott, R. B. (1965). Proc. roy. Soc. Med., 58, 453.

Ship, I. I., Merritt, A. D., and Stanley, H. R. (1962). Amer. J. Med., 32, 32.

Shklair, I. L., Mazzarella, M. A., Gutekunst, R. R., and Kiggins, E. M. (1962). J. Bact., 83, 785.

Sircus, W., Church, R., and Kelleher, J. (1957). Quart.J. Med., 26, 235.

Smith, P. F., and Morton, H. E. (1951). Science, 113, 623.

Taylor-Robinson, D., Canchola, J., Fox, H., and Chanock, R. M. (1964). Amer. J. Hyg., 80, 135.

-, Ludwig, W. M., Purcell, R. H., Mufson, M. A., and Chanock, R. M. (1965). Proc. Soc. exp. Biol. (N.Y.), 118, 1073.

_-, Fox, H., and Chanock, R. M. (1965). Amer. J. Epidem., 81, 180. 